\title{
THEORETICAL AND PRACTICAL ISSUES IN THE IMPLEMENTATION OF CASE-BASED NETWORKING IN THE FIELD OF SPECIAL EDUCATIONAL NEEDS
}

\author{
TiINA KaLLAVUS, VALLO REIMAA
}

Tartu Herbert Masing School, Estonia

\begin{abstract}
Numerous research results show that today's society is characterized by deep and unresolved issues which have also found their way into the school life and influence the pupils' well-being and how well they cope in the school environment (Käst 2010: 3). In searching for a solution, what is usually lacking is a systematic and holistic approach. Estonian scientists find that the starting point for the changes that have taken place in the Estonian education system over the last decades has not been the comprehensive development of the education policy and the changes that have occurred have not been systematic and consistent enough in their assessment (Rinne et. al. 2008: 15).

Under the pressure of the politics of new liberalism that dominated concessions were granted in the education policy that were more characteristic of a free market economy and which were guided by the ideas of competition, the free choice of the client, and sponsorship. In parallel with the triumph of liberal ideology in the 1990s, what also began was the forceful moving of postmodernist discourse next to and in place of modernist discourse. The research results of $\mathrm{K}$. Aava, however, show that in educational texts, liberal discourse is weakening whereas conservative discourse is gaining in strength (Aava 2010).

Yet, studying only discourse that can be found in educational texts might not give enough relevant material for analysis because, for example, research done by K. Lukk reveals that there exists a significant chasm between theory and practice in Estonian educational reality. What is more, the values of parents
\end{abstract}


and teachers do not coincide which makes it difficult to set common goals in a child's development (Lukk 2008: 4-5). It is no secret that an effective cooperation between the school and the home is first and foremost based on good relations (Sutton 2006; Vincent 1996). Good relations in turn are rooted in trust. Building this, however, is a long and complicated process and it is dominated by two main aspects: shared values and communication. K. Lukk points out in the conclusion of her research that it is necessary to create a new way of thinking - instead of being strictly connected to specific forms and methods, the school and home should work together to find a form of cooperation for each individual child and hisher family (Lukk 2008: 4-5). The field of education as a whole urgently needs a new way of thinking and what mostly hinders this is getting stuck into established patterns of thinking and attitudes.

\section{RESEARCH PROBLEM}

In the practical everyday work of the authors it clearly becomes evident that the absence of sufficient cooperation between the education and social fields (and between the respective services) in the development of special-needs children has created a favourable opportunity for the arising of difficulties in coping and hinders the all-round preparation of these children in the best way possible for the independent life as an adult (Kallavus 2010).

As a result of the aforesaid, the authors have formulated a hypothesis that there exists a contradiction in Estonia between:

- the needs of society (from being subject-centred to being pupil-centred, individual approach, etc.) and the kind of school culture that dominates in practice;

- the needs of today and those that are expected (the challenges facing education) and the ability of Estonian education to respond to them (by developing the necessary services).

The following goals were set: 1 . to present the conceptual starting points of the thought culture necessary for building the education service of special-needs pupils as a case-based networking; 2. to formulate the framework proposals for building an education system in Estonia that is based on case-based networking.

The following is an overview of the initial research results which were based first and foremost on such philosophical-methodological approaches as critical 


\section{theory, pragmatism and (social) constructivism/social constructionism} and the following recurring principles were focused on: holism, systematic approach, contextuality, networking.

\section{POSTMODERNISM AND EDUCATION}

What connects the oftentimes quite contradictory approaches of the researchers of postmodernism is the opinion that postmodernism is characterized by the loss of originality and historical truth, as well as by the loss of artistic values and standards, fragmentariness, indeterminacy, pluralism. What dominate in the respective cultural manifestations are irony, fragmentation, discontinuity, playfulness, parody, hyperreality, and simulation (Kraavi 2005; Malpas 2005: 5; Viires 2008: 11). For example, Fuller argues that it is precisely postmodernism that has enabled universities to be divided into countless encapsulated scientific fields which is characterized by an ever-growing lack of interest towards one another (Fuller 1999: 586). The same can be observed in the general education despite all of the attempts to change the course. To understand this, it is enough to compare today's basic school with Käis or Taba's one-time statements and with memoirs on the topic.

Defining postmodernism can be done above all by forming a contrast with modernism. Enlightenment philosophers formulated the positions of modernism already in the $18^{\text {th }}$ century and according to J. Habermas modernism means the cultivation of objectifying sciences, the universalistic general principles of morals and justice. Modernism is characterized by the belief that it is possible to reach the truth through thinking. This kind of optimism is based on science and education. As a result of the aforesaid, in the modernist world, phenomena are evaluated according to the criteria of rationality and intellectuality. What take centre stage are the individual and the individual's intellectual freedom. At the same time, modernism also brought along breaking with a tradition, the replacement of a religious worldview with a secular one, and an appreciation for progress and change (Viires 2008: 12-13).

The modernist paradigm ruled as an autocratic dominant until the end of the $19^{\text {th }}$ century and thereafter existed side by side with postmodernism until the latter rose to become the dominant in the second half of the $20^{\text {th }}$ century (according to different assessments since the 1950s or 1960s or even later decades). At the same time, several theorists of postmodernism have simply seen postmodernism as an extreme expansion of some of the features of 
modernism (Viires 2008: 10,13). Today's society is described as already proceeding into a period following postmodernism that has not yet been precisely defined. Postmodernism brought along a so-called "new education sociology" which offered the ideal of intellectual freedom through education. Regardless of the social background, everyone gained the right to criticize the positions of scientists, philosophers, and others individuals regarded as experts and to develop their own theories. At the same time, by disregarding the objective truth as the goal, the new education sociology robbed itself of the means to justify and implement their own programme. In the worst case, the new education sociology created a theoretical basis for the arbitrary criticizing of any kind of authority by any interest group (Young \& Muller 2007: 181182). Thanks to postmodernism, schools lost their former "monopoly on truth" and the material a teacher discussed in class became merely hisher own personal opinion which is unfortunately also more boring and difficult to grasp than what the media, Internet, or friends offer.

The courage of a great figure in the new education sociology M. Young to re-evaluate today his own previously held views deserves recognition. Differently from the past, he now underlines that the social origin of knowledge is not a reason to doubt in truth and objectivity but, vice versa, the main reason to strive towards objectivity (Young \& Muller 2007: 183).

The second neopositivist school, social constructionism, is based on the assumption that reality is socially constructed as a result of the interaction between people (Burr 1995; Gubrium et al. 1994). Berger and Lucmann, the authors of the work The Social Construction of Reality (1966), are convinced that only people together create and then preserve a social phenomenon through social practice. Moreover, people themselves are also socially constructed. Burr (1995: 3-5) has formulated the main principles of social constructionism as follows:

- Social constructionism is critical toward our taken-for-granted ways of understanding the world. Relying on the knowledge that social reality is constructed during interaction between people, nothing can be defined as a predetermined character. Except that a social phenomenon is constructed in a process between people.

- Knowledge and reality are dependent on one another in the process of construction. The knowledge acquired influences the process of construction: every new interpretation is based on the existent knowledge and the production of new experience and understandings creates new knowledge. 


\section{THE QUESTION OF THE TRUENESS OF SOCIAL FACTS}

The central factor in the social theory of the founder of structural functionalism, the French sociologist E. Durkheim (1858-1917), is considered to be the collective notion, or the social fact (Durkheim 1895/1982) and the most problematic part of this is the scientific verifiability of the social fact. In order to avoid this dead end, the authors of the present article find that one of the solutions is to rely on pragmatic philosophy and its experience of the theory of truth which was founded by the American philosopher C.S. Peirce (18391914). From the perspective of pragmatism, the primary source of truth is experience and actually doing something. In the words of another American pragmatic philosopher and psychologist W. James (1842-1910), the truth of an idea is not its natural and fixed quality, events make it true instead. Trueness actually is an event, a process: namely verifying it, the process of verification itself. Truth is made during experience. Truths emerge out of facts but, at the same time, they also submerge back into facts and bring addition to them; those facts in turn create or manifest a new truth (the word is not important) and so on, indefinitely. In the meantime, however, "facts" themselves are not true. They just are. Truth is the function of beliefs. It resembles to the growing of a snowball that occurs on the hand thanks to the distribution of the snow and on the other hand thanks to the boys' pushes following one another and, at the same time, these factors constantly codetermine one another (James 1997: 8).

The pedagogical teachings of the third great pragmatist J. Dewey have directly been built upon his extensive psychological and logical, ethical and socio-psychological experience, relying among other things on the practical experience of a test school at the University of Chicago. Dewey's pragmatism, which he himself calls instrumentalism, underlines the social importance of truth. It is thanks to Dewey that most American pragmatists have begun to talk about ideas as instruments of the interpretation and organization of experience, about the instrumental character of thinking, about the growth and usefulness of truth, etc. (Koort 1935: 4).

A comparison can be drawn with the school of cognitive psychology that also remains between extreme determinism and freedom. Their point of departure is that our cognition is not a one-to-one copy of the world but a biased process instead that takes place within a certain framework. A figure is more easily associated with an emotion than a word or a concept. At the same time, 
figurative images always feed us a certain way of looking at things and thereby reduce our free will (Kolga 2009: 4).

The area of contact and point of convergence of different subjects and action systems is filled by practical training (Noorväli 2009: 4), as a result of which several theoretical treatments in the field of educational sciences have drawn a link between practical training and learning (see for example Bourdieu 1977; Griffiths et al. 2000; Pohjonen 2001; Lasonen 2001)1. Relying on the historico-cultural action theory of L. Võgotski and his disciples, the famous Swedish educational scientist $Y$. Engeström founded a school respected in the world about the development of action systems, learning, and the transfer of knowledge from one action system to another (Noorväli 2009: 12). His connective model is based on reflective learning and action theories and strives to connect learning at school and work, vertical learning at school, which means moving towards more and more abstract and complex knowledge that is more highly valued by experts, and also horizontal learning at work where the knowledge grows more in width than in depth and the development of the learner moves toward the practicality of the knowledge and the expansion of the horizons rather than some kind of a "higher" knowledge. The model of Engeström had a lot in common with Dewey's theoretical views on education (Noorväli 2009: 13-14).

\section{PRINCIPLE OF SYSTEMATICITY}

The German sociologist and theorist of society N. Luhmann (1927-1998) asks that how can closeness directed at itself create openness (Luhmann 2009: 27). One of the central methodological issues arising from the objective of the present research is precisely related to the fact that every theory seeking universality unavoidably also acts as an object of itself, otherwise it would have to relinquish its objectivity (see Luhmann 10-11). It is precisely the practical implementations of such theories that over time become restrained by the tendency to lean towards voluntary closeness, the solutions become rigid and lose their ability to adjust and be creative. Focusing on the unique solution to the actual case becomes replaced by imitating a solution that is supported by

\footnotetext{
1 In Estonia, what is still understood under practical training is practical work with specific learning objectives done within the framework of a study programme in a working environment and under the guidance of a supervisor (Vocational Education Standard $\$$ 8; Vocational Educational Institutions Act $\$ 17)$.
} 
various strategies of justifying oneself. In the end, the situation is basically back in the starting point, search for the culprits begins, a rephrased and re-encoded (but essentially the same) universal theory is rediscovered and everything begins all over again.

In the opinion of the authors of the present article, what offers the best opportunity to mitigate the effects of this essential contradiction is the implementation of the achievements of the general system theory that rapidly evolved in the second half of the $20^{\text {th }}$ century and that hopefully is becoming an instrument for overcoming the prolonged crisis of the modernist society (which is usually referred to as postmodernism).

N. Luhmann particularly underlined the importance of including the system theory in the development of the science of sociology and what he had in mind was precisely the general system theory that he regarded as a pragmatic change in comparison with the Newtonist modern system theory. The distinction between the whole and the part that had persisted since the antiquity was now replaced with the distinction between the system and the environment (Luhmann 2009: 16-24).

The starting point of the general system theory were first formulated by L. von Bertalanffy who began to draw a distinction between open and closed systems that are located in a certain environment and, furthermore, both of them are made up of parts connected to one another and are more than just a sum of their parts. Open systems are characterized by a constant contact with their environment. N. Luhmann also emphasizes that systems do not consist only of connections between the elements because the relationship between the elements is also regulated (Luhmann 2009: 46). His central thesis says that the social system consists mainly of communication (and not of subjects, individuals and other things like that) and functions in autopoiesis through which the system produces and reproduces itself.

Von Bertalanffy formulated the concept of the system as follows - system is a structure that is defined by its parts, the processes between them, and the input and output. One and the same phenomenon can be described through different system. A system consists of its elements, attributes (features than can be perceived and measured) and connections that form between the elements and attributes. A system is hierarchically divided into subsystems and these in turn into subsystems and a system on one level can be a subsystem on another level. Thus a child can be viewed as part of the system of family and, at the same time, family can be viewed as part of the system of the child. What regulates these 
connections is the principle of conditioning which means that a certain connection between the elements is realized only on the condition that something else either exists or does not exist. Every time one speaks of "conditions" or "conditions of possibility" (also in the epistemological sense) what they have in mind is this concept. From the principle of the unity of structure and function comes the principle of the dual treatment of systems. Any real system can only be comprehensive and hierarchical. Of these two features, comprehensiveness is primary and it acts as a factor triggering hierarchicality (Luhmann 2009: 46; Meriste 194-195).

In addition, all systems are characterized by the principle of contextuality or, in other words, by the existence of background systems(s) and there exists a border between the system and the context (the environment). The environment/context can be defined as a place where the system acts as objects that influence the behaviour of the environment. It is precisely the principle of contextuality that is related to von Bertalauffs idea of open and closed systems. For example, in the case of the development of schools, what can be observed is how they have moved from a relatively closed system towards a more open system. What is meant under openness here is the ability to change with the environment while at the same time retaining a constant balance. Being balanced is part of the main criteria of describing a system together with openness and closeness.

The concept of the balance of a system can be illustrated very well with a school that should accomplish externally determined academic goals while, at the same time, also bearing in mind the pupils' individual capabilities and needs. Schools are always fighting for an inner balance. Under certain conditions, this can also take the form of resisting change.

A family is system-theoretically conceptulizable through its inner relations and the individual as a subsystem of the family, through the relations between the family system and the external environment. Every individual member of the family is organized as a system living simultaneously in different places and that has biological, psychological, and social characteristics.

The same theoretical framework can be used to examine the relations between a child and school. Similarly to a family, a school also consists of the action patterns of individuals that are directed towards certain goals, it has its own subsystems and borders and consequently the framework of a system is suitable for examining a school. The challenge of a school is to integrate the individual experiences of its members into a meaningful whole. The starting 
point of this integration is the recognition that all the school's processes, procedures and actions form a whole and every component influences it and its other components while at the same time also being influenced by them in return. A common recipe for the successful functioning of the systems of school and family is clearly defined borders, communication, and coherence between the subsystems (Rendall \& Stuart 2005).

\section{PRINCIPLE OF CONTEXTUALITY}

One of the direct predecessors of the general system theory was the Estonianborn J. J. Baron von Uexküll (1864-1944) and founder of biosemiotics who brought into biology the term Umwelt, developed significantly further ecology ${ }^{2}$ and was an intellectual role model for cybernetics as well as radical constructivism (including for the founder of the theory of autopoiesis H. Maturana, in philosophy for E. Cassireril, O. y Gasset, M. Heidegger, G. Deleuze and others).

By looking at the ecosystem as a whole, the relations between its parts and their functioning, ecology focuses on the examination of circulations, relations between organisms, and on the environment ${ }^{3}$ that is related to them. At the same time, a school can also be viewed as a comprehensive ecosystem and the classes as its subsystems. The principal research object of ecology is the circulation and the flow of energy in the ecosystem - in a school, respectively, the synergy mechanisms of the institution as a whole and its subsystems under the conditions of the prevailing general context.

In ecology, the concept of "balance" plays an important role and it can mean at least three different things: 1) the ability of an association to resist change; 2) stability or the ability to stay in a certain size; 3 ) recovery or the ability of an association to regain its previous level following some kind of damage. The more balanced an association is, the more quickly it will recover. What should be avoided are such unrecoverable changes an association cannot recover from

\footnotetext{
2 The concept of ecology was first used by the German biologist, naturalist and philosopher E. Haeckel in 1866. The term "ecosystem" was fisrst formed by the English florist A. R. Clapham in the early 1930s but it became more widely used through the works of the plant ecologist Arthur Tansley (since the year 1935).

3 The environment or milieu (in German Umgebung, Umwelt) is the system of things, conditions, and relations that can encompass the whole world in its diversity but can also, for example, be natural (ecological, biological), economic, social, cultural, technological, etc.
} 
on its own. What can be viewed as a change of this kind is, for example, the constant changing of the student body in a class which actually takes place all the time throughout the whole school year in a special-needs school. When speaking of the balance of a class (and a school), it is most useful to concentrate on the study of the limit conditions of recoverability.

What evolved on the direct influence of Von Uexküll's works as a branch of the general system theory was system biology and the latter term was first used in 1928 by von Bertalanffy himself. What grew out of the general system theory was the so-called Living systems theory that was founded by J. G. Miller (1916-2002) whose main work Living Systems was published in 1978, almost at the same time was also born Bronfenbrenner's (1917-2005) socalled Ecological Systems Theory, sometimes also referred to as Development in Context or Human Ecology. What is related to the latter is the so-called Context theory, one of the founders of which Wilden emphasizes in his research System and Structure the importance of the ecosystem as a selforganizing system and of the ecological approach (Widen 1972).

The organizational theory of the American psychologist K. Lewin (18901947) is based on the field theory formulated by him and the concept of life space. Lewin, however, was originally involved with the behavioural psychology of schools before entering the field of science and gestaltpsychology. Lewin treated the social environment as a dynamic field that is interacting with a person's senses. A person's psychological condition is therefore influenced by the social field or milieu and he focused on the subjective components of the environment and their meaning in a person's life. His students Barker and Wright were interested in those parts of the society where a person's behaviour can be observed, analogically to the ecological environment. Those parts of the society can be viewed as the context of the behaviour that depended on the following factors: place, time, physical characteristics, activeness, participants, roles. Those kinds of contexts are, for example, a parents' house together with the family living there, a classroom together with the class and teacher belonging there, etc. In those contexts, the individual is in direct contact with social partners. An individual's development cannot be viewed separately from those contexts or, in other words, developmental environments. Changing the context can mean a change in the behavioural patterns - thus development cannot simply be viewed as acquiring new ways of behaving but as adjusting to new environments and to the requirements they set. 
System theory has had a great impact on social work. What is taken as the basis is the principle that a satisfiable life depends on the systems of a person's closest social environment. Social work and among that child protection work deals exactly with these system (Payne 1995: 26). Pincus and Minahan (1973) present a direction of social work that directly implements the ideas of system theory. According to their classification, people can be helped by two kinds of systems: 1) informal or natural systems (family, friends or colleagues) and 2) formal systems - community groups or associations, societies and systems of the society (hospitals, schools, day centres or rehabilitation institutions) (Payne 1995: 112)

\section{THE PRINCIPLE OF BEING CASE-BASED}

As a result of their analysis concluding their longstanding material of experience, the authors find that the central questions of the principle of being case-based are as follows:

1. What is the truth, the criteria for assessing development, for the given case?

2. What is the context of the given case?

3. How do the case and its context build up as a mutual synergy network?

4. What is the suitable intervention strategy for the given case and the resulting tactical steps?

5. What is the cooperation organization like governing the planned actions (the case management solution) and the communication system keeping it functioning?

6. On the basis of what kind of criteria and how to recognize that a given case has to be closed and transferred to the case management of the next subsystem in the holistic health system?

The best answer to the first of these questions is given by the pragmatist conception of truth described above. Namely, in the opinion of Dewey, the method cannot be separated from the material and changes individually. This idea can also be extended to the organisation of studies. Dewey's whole pedagogics derives from the conviction that learning is only possible through action (learning by doing). At the same time, a school cannot become a vocational school, even though it is based on different forms of practical activity (occupations). In order to realize these goals, he farsightedly advises to break away from the standardized educational path that has only been made 
suitable for the preparation of academically educated people, at the same time also referring to statistical data in quite a modern way which show that many pupils leave school already at the basic school level because studies are too theoretical for them and they do not see any point in continuing with their school work (Koort 1935: 4-5).

The principle of being case-based derives from the principle that everything that happens is real and we can plan activities that guarantee the building of sustainable balanced social systems only by relying on the specific and unique reality. A different issue is the question about what kind of methodology better enables to take into account this changing and unique reality that is always slipping away? There can only be one answer here as well - this methodology also has to be case-based, unique, and as flexible and continuously changing.

The applied version of the principle of being case-based is called case management and nowadays this is very common in social work, but unfortunately not in the field of education. What is common is the treatment of case management on the one hand as a process of problem solution and on the other hand as a system that functions thanks to administrative support, systematic management, as well as the inclusion of formal and informal community resources (O'Connor 1988, cited in Wood, Tully 2006: 169).

Based mainly on the experience of the social field, literature distinguishes between the following generalizations of the actual practice of case management:

1. The role-based or generalist model of social work where the case manager himselfherself does a lot of client work and is in different roles as the need arises, such as the mediator, counsellor, coordinator, etc.

2. The organization-based or case-management working group model which has been created to offer a service package as wide-ranged as possible primarily for clients with issues related to mental and physical special needs. Every member of the interactive group has a function with a clear purpose in providing the services (social work, physiotherapy, speech therapy, etc.).

3. The duty-based case management or supportive care that is based on the client's natural environment and takes place in the client's close network. The tasks of the case manager are here performed by a family member, a member of the network, or a volunteer who have been prepared for this, or by the client himselfherself. 
Case management involves two kinds of networks and working within/with them: the network of specialists/service providers and the close network of the client / family (Wood, Tully 2006: 170). International literature draws a clear line between the case management dealing with formal networks and the work with a client's close network done within the framework of a specific service.

In applying the principle of being case-based in the education practice, it has to be borne in mind that, for example, the critical analysis of the Australian researcher and theorist of social work J. Fook shows that applying case management by order makes it not function. Fook suggests that in a situation where the management and administrative checks of the apprentices and clients become more and more frequent, case management becomes a way of working that concentrates on the system rather than on the client, serves the interests of the administration rather than vocational interests or those of the client, is technocratic and simplifying rather than multifaceted, holistic and directed towards the long period and, as a result, cares less about personalized, individual needs, being driven mainly by economic-rationalistic principles. This can cause the shift of attention from addressing the clients' needs to the fact whether the clients are guided and coordinated properly, and what develops is a competition inside the system to become the most legitimate case manager in the given context (Fook \& Gardner 2007)..

Every case lives in its specific environment and one can distinguish between the impact of different contexts (family, community, school, and peers) on a child's development. A framework for this is offered by Bronfenbrenner's ecological system theory. Analogically to biological ecosystems, Bronfenbrenner attempted to describe the development of a human being in the ecological system where the change of one element in the system (as, for example, the birth of a new child into a family) changes the whole system. Wishing to understand and change the pupils' behaviour, we therefore have to examine and take under consideration the environment (the context) in which the behaviour takes place (Nordahl 2002). However, the link between problem behaviour and school context is not always clearly identifiable as the problems referred to always have several contributing factors. In addition, pupils act as subjects capable of choosing their own actions (Bø et al. 2003).

Unfortunately teaching/educating can only be viewed to a certain extent as an instrumental undertaking in which we unanimously and objectively discover and decide what kind of methods, principles, goals and content of the organization ensure the best learning results. This is a multilateral active 
process where nowhere near everything can be planned in detail. What are crucial for the planned intervention activities are the relations between the participants and their quality.

\section{SUSTAINABILITY, COHERENCE, TRANSITIONING}

What are increasingly seen as problems are weak integration between the educational stages, an emphasis on academic results, and little attention on the attaining of study skills and educational goals (Bracken \& Fischel 2007, Huffman et al. 2000, Lõoke \& Saarits 2004, Leino 2005, McIntyre et al. 2007: 67; Penjam 2004; Petriwskyj et al. 2005: 58-59; Pianta \& Kraft-Sayre 2003; Sarv 2006: 22-24; Webster-Stratton et al. 2008: 471-473).

In the context of the present article, it is important that a child's personal coping at every new educational stage is connected with such social skill as adaptability. A learner who transitions from one educational stage to the next one has to adapt to new kinds of circumstances and use different strategies in order to cope with the external and internal requirements. For example, German and Gitterman's "life model" of social work that has grown out of the ecological system theory treats people as constantly adapting in interaction to the many different aspects of their environment (Payne 1995: 114).

In assessing the sustainability of education, one has to consider a child's coping in the transition process from one educational stage to the next, bearing particularly in mind the realization of the general goals of the study programme. In reality, however, this is only measured by extremely formalized marks on the leaving certificate which generally are very weakly linked with the study programme's general competencies (see for example Kukk 2010: 9).

In the Social Welfare Act (1995) coping has been defined as a person's or family's physical or psycho-social ability to cope in their everyday life. This definition is individual-centred, disregarding the environment. According to Lazarus (1980), a person needs two main skills to cope - solving problems and overcoming negative emotions. For both of these, a person needs hisher own as well as the environment's resources (Viiralt 1999). The coping of a disabled child can be supported by a method of social work - empowerment which relies primarily on the child's strong qualities, thus improving hisher ability to act and cope. What plays an important role here is the environment, particularly its social parameters (relationships, roles), the competence of the rehabilitators also matters (Viiralt 1999). 
Coping is directly linked to adaptability, in connection with which what are treated as basic skills are the skills related to learning to study and attaining the general educational goals which have been grouped into the following categories: a positive self-concept, study motivation, academic skills and cooperation skills. The category mentioned last relies on the existence of social skills (Kukk 2010: 19). In practice, the greatest problem is evaluating actual coping in transitioning from one educational stage to the next.

The most important component of adaptability, however, is socializing which means the acquisition of experiences and value orientations in order for a person to fulfill hisher social roles. Socializing is a constant process during which the formation of the personality takes place that ensures the consistency and preservation of the individual and the social group (Aimre 2001: 160162).

A person's social life includes stages and cycles of different social quality.

During socialization different social experiences are stored in every period of the life-span. Values and value orientations develop and change and different resocialization also takes place. What is important about socialization is that in every stage, some new socialization agents start to program it: school comes next to the family, schoolmates and participants in hobby schools come next to the playmates, etc. (Aimre 2001:166).

According to the principles of sustainable education and child-centred pedagogics, a child's adaptability and coping depend to a large extent on the environment where he/she grows up (Kukk 2010: 10). In the assessment of L. Võgotski, the environment where one grows up has its own specific physical, psychological, social, cognitive, and emotional factors during preschool as well as school which have to be taken under consideration when creating a learning environment that supports a child's all-round and sustainable development. When transitioning, for example, from one education institution to another, the influences of the two different systems integrate. A child's wish to learn has to receive new stimulations that also consider hisher previous experience and level of development (Kukk 2010: 11). Similar kinds or even more serious adapting issues arise due to familial changes.

In the transition process from one system / environment to another, what becomes important is a child's readiness for the transition. In the education system this complex concept designates a child's physical, social, and psychical level of development for systematic and intentional studying (Broström 2003; Tulva 1987; Veisson, Veispak 2005) that begins in the preschool period and 
continues without interruption during the first school years in the school context (Broström 2003; Hytönen 1999).

Bronfenbrenner describes a child's transition from one microsystem to another as an ecological transition. The process of transition depends on whether the rules that apply in the new microsystem are in contradiction with the ones that applied before, whether the new rules are explained, whether someone from the old microsystem accompanies during the transition (Bronfenbrenner 1992).

The more aware a teacher and parent are of a child's transition issues and peculiarities, the more smooth the transition from one educational stage to another and the more sustainable a child's development, which requires from the teacher a very good understanding of the education reality, readiness for discussions, and the ability to analyse one's own development (Krull 1998). What is important in the teacher's action is focusing on the primary coherence between the educational stages and acknowledging the importance of the transition period and sustainable learning. The teachers of both educational stages have to perceive as their goals in the transition period the attainment of the objectives of the study programme in cooperation (Biggs \& Tang 2008; Broström 2003; Hains et al. 1989; Hargreaves \& Fink 2006; Kukk 2010: 32).

Engeström came to the conclusion that the development takes place by way of the interaction between the action systems and represents the developmental transitioning of knowledge (Engeström 2001; Tuomi-Gröhn \& Engeström 2003: 27) that starts with questioning the existent practice that is followed by its analysis, the modelling of the (future) practice desired, then by the testing, implementation, and assessment of the model. In the course of this takes place the construction of the so-called limit object and the transition of knowledge between different action systems, the construction of new practices, concepts, and theories (Engeström 2004: 60-61). In Engeström's treatment expansive learning also includes most of the known learning models experiential, reflexive, situational, social, and transformative learning (Noorväli 2009: 16).

In the end, the question is not so much about the decontextualization of the previously acquired theoretical knowledge, but about their recodification and implementation in the service of a specific practice and its improvement (Noorväli 2009: 18). 


\section{SOCIAL NETWORK}

In analyzing the relations between people, G. Simmel (1908) was the first to start to use the term social network which in his treatment means a "chain" of those people who are connected to each other (neighbours, relatives, self-help groups). Sometimes the terms social support network and social support system are also used as synonyms (Korp 2002). The social network can be viewed as a system of intertwined relations. The classical definition of social network comes from J. C. Mitchels: "Social network is a model of contacts /relations/typical of a group the characteristics of which help to explain the behaviour of the individuals belonging to the group" (Kiik 2001).

The social network therefore means all the relationship networks of an individual. When social support is received from certain people belonging to the network, then this forms the support network which is smaller than the whole network. The whole system, however, includes networks of close as well as formal relations (Korp 2002; Tulva 1996).

In the practice of social work, the most wide-spread approach that emphasizes networks is related to the ecological metaphor, systems theory, and ecosocial approach (Bronfenbrenner 1979; Healy 2005; Collins et al. 2007, etc.) that in the understanding and building of networks relies on the individual that is linked to and receives feedback from the context with which it forms a common ecological synergy system.

The ecological system theory has been integrated with the constructionist theory (Kilpatrick, Holland 2003; Iversen et al. 2005). The ecosystematic approach helps to comprehend the action field and the constructionist/narrative experiences/meanings in it. This kind of integrating helps to partly deflect the criticism the ecosystematic approach has received. For example, Healy (2005: 147-148) claims that the "fundamental truth" according to which a change in one part of the system triggers a change in the other parts and the whole system involves knowledge that is to a large extent intuitive and untested. It is, of course, the truth because the general system theory assumes an inevitable need to every time independently identify the influences of the system and the context. There do not arise any fundamental truths from the general system theory that are automatically carried over besides the principles of the structure of the system itself. In general, this trivial fact is not regarded as guiding the phenomena falling under social systems, whether it be the school, the kindergarten, or the education network as a whole, at least not in Estonia. 
A network, including a social network, is characterized by: wholeness (holism), coherence (communicativity), hierarchicality, and the constant changing and intertwining of the roles of the subject and object, as well as those of a member and the environment.

In the discourse of the social field, "network" and "networking" are used as metaphors as well as terms. The word "framework" is also used, but considerably less. As any other system, a network also consists of members and the relations and communication between them (Korp 2002). Networking, however, means active and intentional intervention activities into the working mechanisms of a specific network.

Even though the importance of a child's close network is often emphasized, in practical work, the main attention is usually on the networks of officials and specialists. Unfortunately, the participants in the networking also perceive it as being restricted in this way. In addition, the interpretation of the central subject of the network is also inconsistent: sometimes it is the child, other times "the child's problem," then the family or even the child protection official (Selg 2007).

\section{THE MAIN ELEMENTS OF THE EDUCATION NETWORK}

Differently from the widespread opinion that the main elements of the education network are the pupil and the school, they should still be considered to be the pupil and the learning situation. The latter usually takes place in a classroom (less frequently in an individual study room), but they can also be the learning environment at home and all kinds of learning situations outside the classroom and the home.

The main elements of the learning situation in addition to the pupil (who is again in the central place) are also the teacher (or some other person fulfilling the same function), the spatial environment, aids (including teaching materials), and regulation mechanisms (for example, legislation, regulations concerning organization of study, informal regulations, oral agreements). From the subsystems what belong here as the main ones (depending on the learning situation) are the family, friends, members of the class, all of them are described by Bronfenbrenner by the term microsystem. The subsystems referred to at the same time also belong among the systems of the next level, the most institutionalized among which is, of course, the school (also the kindergarten, hobby school, etc.), in other words Bronfenbrenner's mesosystem. Contrary to 
Bronfenbrenner's ideas, a class is only initially part of the mesosystem (when entering the first grade, when changing schools), thereafter slowly becoming the microsystem of the adaptation process. The same thing occurs from the child's perspective also with the circle of friends and its changing, as well as with the family in case of a divorce or the emergence of a stepparent.

The primary system, however, is the pupil himselfherself. The level of hisher individual development, however, depends most of all on the primary microsystem in which the child spends hisher time - on the family (including the background of the parents, their childhood experiences, the surrounding growing environment, the state of health, the gene pool, etc.). Significant influences are also the attitudes, values, and ideological dispositions of the parents (Klefbeck \& Ogden 2001; Tulva \& Viiralt 2001; Leppiman 2002). According to Bronfenbrenner, the last one falls under the macrosystem, whereas the size and structure of the family, interpersonal relationships, and health belong to the microstructure (Leppiman 2002).

In the case of the exosystem and macrosystem, the child does not anymore have a direct physical interaction, even though the processes related to them influence the environment where he/she lives and through which the child's world expands (Kiik 2001; Leppiman 2002). Bronfenbrenner's system levels existing together at a given point in time are essentially simply different kinds of relations and the social memory stored through them, and incidentally, the exosystem and macrosystem become realized mainly through the microsystem and mesosystem, but also through the space environment that remains between them - the public space (together with the institutions and enterprises that belong to it), including the street, transport vehicles, natural environment, etc., and the private space (the apartments and households of the circle of acquaintances).

Because the synergy network can only be built upon real subjects, what can come under consideration in networking are only the child (together with selfreflection) and hisher microsystem and mesosystem. From the perspective of the child, the main task of the synergy network is to ensure that he/she copes better and to unite the education system, the social system, and the medical system together as the subsystems of one comprehensive system. Consistent and thorough documenting of the child's development, however, is nothing other than the chronosystem of the ecological system theory in its materialized form. It also forms the central axis of the communication system that unites the networking connected with the child. 
Because a functional comprehensive system is only possible through sustainable connections and transitions, it has to be borne in mind that: 1 . transition is a process that has to be supported by legislation and political measures; 2 . the young person has to part of the transition process and hisher choices have to be respected; 3 . transition is part of a long and complex process that prepares the young person for entering the adult and working life.

Every system needs regulation to function and this has to be based on the same holistic principles and sustainable transitioning between the subsystems as the network theory described above. All the more so because in the assessment of R. Maruste, the right to education entails the positive obligation of the state to regulate the respective field (Maruste 2004: 506). What follows from the obligation to study in turn is the need for minimum standards concerning the organization of study (see about this the Commented Edition of the Constitution of the Republic of Estonia 2002: 644; Alexy 2001: 29, 78; Veermäe 2004: 714; Annus 2006: 370). The fact that as a general rule, the pupils' opportunity to choose increases as they reach higher levels on the education ladder (Comparative administrative politics: 29) presupposes the establishment of minimum standards according to the stages of study, whence we move on to the minimum standards regarding different types of schools and classes (including the quality requirements for the classrooms, the technical aids, the support personnel, the safety of the school environment, the structure of a school day, etc.) (Reimaa 2008). In the end, however, all these different standards have to be brought together into a united whole and the transitions between them have to be described and composed through. Otherwise we would largely be dealing merely with labelling.

\section{CONCLUSION}

An ideal situation is where the medical system, the social system, the education system, as well as the child and the family act in a coordinated way, with a clear division of responsibility and tasks for the purpose of achieving the child's maximum developmental, intellectual, and health potential and good coping.

Medical care assesses the need for medical aid (determining the cause of the health disorder, treatment with medicines, surgical treatment, rehabilitation, health check, etc.) and guarantees the availability of the necessary aid. 
The social sphere assesses the person's need for external help and support services in order for him/her to cope and guarantees the necessary social assistance.

The education system determines the child's special educational needs and arranges the availability of the relevant pedagogical assistance (appropriate form of study, study programme, etc.).

The education system that is based on this kind of cooperation has to be sufficiently flexible and able to change in order to constantly adjust and develop creatively further the learning system in which the child spends hisher time.

Most importantly, in the legislation framing this kind of an education system have to be described also the sustainability mechanisms or, in other words, the supported transitions from one educational stage to another, from one subsystem of the education network to another, from one subsystem of the support network to another, and, in the end, from the education system to the working world.

\section{REFERENCES}

1. Aava K. (2010). Eesti haridusdiskursuse analüüs. Doktoritöö analüütiline ülevaade. Tallinna Ülikool. Sotsiaalteaduste dissertatsioonid. Tallinn.

2. Alexy R. (2001). Põhiõigused Eesti põhiseaduses. Juridica erinumber.

3. Annus T. (2006). Riigiõigus. Tallinn.

4. Berger P. L., Luckmann T. (1991). The Social Construction of Reality. Penguin:

5. Harmondsworth B., Roberta M. (1985). Child, Family, Community. CBS College Publishing. Holt, Rinehart and Winston.

6. Biggs J., Tang C. (2008). Õppimist väärtustav õpetamine ülikoolis. Tartu: Tartu Ülikooli Kirjastus.

7. Bourdieu P. (1977). Reproduction in Education, Society and Culture. London: Sage Publications.

8. Bracken S. S., Fischel J. (2007). Relationships Between Social Skills, Behavioral Problems, and Readiness for Head Start Children. - NHSA Dialog: A Research to Practice Journal for the Early Intervention Field, Vol. 10, Issue 2, 109-126. http://www.informaworld.com/smpp/content $\sim \mathrm{db}=\mathrm{all} \sim$ content $=\mathrm{a} 788046967$. (29.07.2011)

9. Bronfenbrenner U. (1979). The Ecology of Human Development. Harvard University. 
10. Bronfenbrenner U. (1992). Ecological systems theory. In Vasta R. (ed.) Six theories of child development: Revised formulations and current issues (pp. 187-249). London: Jessica Kingsley.

11. Broström S. (2003). Communication \& Continuity in the Transition from Kindergarten to School in Denmark. http:/ / extranet.edfac.unimelb.edu.au/ LED/ tec/pdf/brostrom.pdf (30.07.2011)

12. Burr V. (1995). An Introduction to Social Constructionism. London and New York: Routledge.

13. Burr V. (2003). Social constructionism. Second edition. London. Routledge. New York.

14. Collins D., Jordan C., Coleman H. (2007). An Introduction to Family Social Work. Second edition. Thomson. Brooks/Cole.

15. Durkheim E. (1895/1982). The Rules of Sociological Method. New York: Free Press.

16. Eesti Vabariigi Põhiseadus. Kommenteeritud väljaanne. (2002). Tallinn.

17. Engström Y. (2001). Expansive Learning at Work: toward an activity theoretical reconceptualization. Journal of Education and Work. 14 (1), 133-156.

18. Engeström Y. (2004). Ekspansiivinen oppiminen ja yhteiskehittely työssä. Tampere.

19. Fook J., Gardner F. (2007). Practising critical reflection: a resource handbook. Maidenhead: McGraw Hill/Open University Press.

20. Fuller S. (1999). Making the University Fit for Critical Intellectuals: recovering rom the ravages of postmodern condition. British Educational Research Journal, $25(5), 583-595$.

21. Goldberg W. G., Tully C. T. (2006). The Structural Approach to Direct Practice in Social Work: A Social Constructionist Perspective. $3^{\text {rd }}$ rev. ed. Columbia University Press.

22. Griffiths T., Madsen T., Wallentin C., McKenna P., Colm Ó’Maolmhuire, Marhuenda F., Cros M. J., Gimenez E., Herlau H., Rasmussen L. B., Christensen L., Krarup G., Benke M., Gorgenyi I. (2000). Work experience as an education and training strategy: new approaches for the 21st century (WEX21C) FINAL REPORT.

23. Gubrium J. F., Holstein J. A. (eds.) (2002). Handbook of interview research. Context \& method. SAGE Publications.

24. Hains A. H., Fowler S. A., Schwartz I. S., Kottwitz E., Rosenkotter S. (1989). A comparison of pre-school and kindergarten teacher expectations for school readiness. Early Childhood Research Quarterly, 4, 75-88.

25. Hargreaves A., Fink D. (2006). Sustainable leadership. San Francisco: Jossey-Bass.

26. Hartman A., Laird J. (1983) Family-centered Social Work Practice. New York, Free Press. 
27. Healy K. (2005). Social Work Theories in Context: Creating Frameworks for Practice. Palgrave Macmillan.

28. Huffman L. C., Mehlinger S. L., Kerivan A. S. (2000). Risk Faktors For Academic and Behavioral Problems at the Beginning of School.

http://www.nimh.nih.gov/childhp/huffman.pdf. (14.01.2009)

29. Hytönen J. (1999). Lapsekeskne kasvatus. Tallinn: Tallinna Pedagoogikaülikool; Sihtasutus Omanäolise Kooli Arenduskeskus.

30. Kallavus T. (2010). Helping children with special educational needs as a coopetation between the fields of education, social work, and medidicine. Papers on Anthropology. XIX. Tartu, 130-144.

31. Kiik R. (2001). Laps ja võrgustikutöö, SA Omanäolise Kooli Arenduskeskus.

32. Kilpatrick A., Holland T. P. (2003). Working with families: an integrative model by level of need. Boston: Allyn and Bacon.

33. Klefbeck J., Ogden T. (2001). Laps ja võrgustikutöö: lapse arengu ökoloogiline perspektiiv ja võrgustikuteraapia meetodid töös lastega. Omanäolise Kooli Arenduskeskus.

34. Kolga V. (2009). Haridus teeb vabaks. Haridus, 1-2, 3-4.

35. Koort A. (1935). John Dewey pedagoogika aluseid. II osa Eesti Koolist nr. 6.

36. Korp, E. (2002). Võrgustikutöö võimalused lapse aitamisel; Laps elu, probleemid ja lahendused, Tallinn

37. Kraav J. (2005). Postmodernismi teooria ja postmodernistlik kultuur. Ülevaade 20. sajandi teise poole kultuuri ja mõtlemise arengust. Viljandi Kultuuriakadeemia.

38. Krull E. (1998). Õpetamise tõhususe hindamine. Tartu: Tartu Ülikool 1998.

39. Kukk A. (2010). Õppekava eesmärkide saavutamine üleminekult lasteasutusest kooli ning I kooliastmes õpetajate hinnangul. Analüütiline ülevaade. Tallinna Ülikooli sotsiaalteaduste dissertatsioonid. Tallinn.

40. Käst J. (2010). Õpetajate ja koolide tugispetsialistide võrgustikutöö tõlgendused ja koolitusvajadused ning soovitused õpilaste heaolu paremaks tagamiseks koolikeskkonnas. Magistritöö. Tartu Ülikool Sotsiaal- ja Haridusteaduskond. Tartu.

41. Lasonen J. (2001). Työpaikat oppimisympäristöinä. Työpaikkajohtajien, opiskelijoiden, työpaikkaohjaajien ja opettajien arviot Silta-hankkeen $(2+1$-kokeilun $)$ kokemuksista. National Board of Education. Helsinki: Hakapaino.

42. Leino M. (2005). Töötu abirahast lapsesõbraliku koolini. Õpetajate Leht, nr. 23, http://www.opleht.ee/Arhiiv/2005/10.06.05/dialoog/1.shtml. (300.07.2011)

43. Leppiman A. (2002) Sotsiaalse sugupoole kujunemisest, "laps elu, probleemid ja lahendused", Tallinn

44. Luhmann N. (2009). Sotsiaalsed süsteemid. Tõlge eesti keelde: kirjastus "Ilmamaa”. Tartu.

45. Lukk K. (2008). Structural, Functional and Social Aspects of Home-School Cooperation. Abstract DOCTORAL THESIS. Tallinn. 
46. Lõoke E., Saarits Ü. (2004). Koolivalmidus - mida ootavad lasteaialt lapsevanem ja algklassiõpetaja? - ÕpetajateLeht. http://www.opleht.ee/Arhiiv/2004/05.03.04/aine/3.shtml. (30.07.2011)

47. Malpas S. (2005). The postmodern. London; New York: Routledge.

48. Maruste R. (2004). Konstitutsionalism ning põhiõiguste- ja vabaduste kaitse. Tallinn.

49. McIntyre L. L., Eckert T. L., Fiese B. H., DiGennaro F. D., Wildenger L. K. (2007). Transition to Kindergarten: Family Experiences and Involvement. Early Childhood Education Journal, Vol. 35, No. 1. (Online).

http://web.ebscohost.com/ehost/pdfviewer/pdfviewer?vid=5\&hid=8\&sid=9242 2183-be60-4704-b716-f824243b0c8f\%40sessionmgr10. (29.07.2011)

50. Noorväli H. (2009). Praktika arendamine kutsehariduses. Analüütiline ülevaade. Tallinn: Tallinna Ülikooli Kirjastus. Tallinna Ülikool. Sotsiaalteaduste dissertatsioonid, 38. ISSN 1736-3675. ISBN 978-9985-58-665-5.

51. Payne M. (2005). Modern Social Work Theory. ( $3^{\text {rd }}$ ed.). Palgrave Macmillan.

52. Penjam T. (2004). Võrdsusest on asi kaugel. Õpetajate Leht. http://www.opleht.ee/Arhiiv/2004/16.04.04/koik.shtml. (29.07.2011)

53. Petriwskyj A., Thorpe K., Tayler C. (2005). Trends in construction of transition to school in three western regions, 1990-2004. International Journal of Early Years Education, Vol. 13, No.1, 55-69.

http://web.ebscohost.com/ehost/pdfviewer/pdfviewer?vid=4\&hid=8\&sid=9242 2183-be60-4704-b716-f824243b0c8f\%40sessionmgr10.(30.07.2011)

54. Pianta R. C., Kraft-Sayre M. E. (2003). Successful kindergarten transition. Baltimore: Paul H. Brookes Publishing Co.

55. Pincus A., Minahan A. (1973). Social Work Practice: Model and method. Itasca: F. E. Peacock.

56. Pohjonene P. (2001). Työssäoppiminen tarkasteltuna ammatillisen aikuiskoulutuksen ja työelämän näkökulmasta. [Academic dissertation.] Tampere University. Juvenes Print.

57. Reimaa V. (2008). Haridus kui põhiõiguslik kohus ja miinimumstandardid. Põhikool annab põhja. 11. ja 12. jaanuar 2008 Väimela. Ettekannete ja artiklite kogumik. Koost. Olav Aarna. Tallinn 2008.

58. Rendall S., Stuart M. (2005). Excluded From School. Systemic Practice for Mental Health and Education Professionals. London, New Yprk: Routledge

59. Rinne R., Jõgi L., Klemelä K., Korpas M., Leppänen R. (2008). Soome ja Eesti ühisprojekti Suviko (Suomalainen ja virolainen koulutus aj EU:n uusi koulutuspolitiikka”) lähtekohad. Jõgi L., Jääger T., Leppänene R., Rinne R. (koost). Eesti ja Soome haridus ning muutused ELi hariduspoliitikas 1990-2000. Tallinn: TLÜ Kirjastus, 11-16.

60. Sarv E. S. (2006). Õpetaja ja kool uuringute peeglis. R. Vürmer (toim). Elukestev kutseõpe - tõkked ja sillad. Tallinn: Eesti Haridusfoorum, 85-112. 
61. Selg M. (2008). Lapsekesksuse tõlgendusi Eesti lastekaitse käsiraamatute võrgustikutöö juhistes. A. Rämmar (Toim), Vaateid teelahkmelt. Sotsioloogia, sotsiaaltöö ja sotsiaalpoliitika aktuaalseid probleeme Eestis (lk 167-188). Tartu Ülikooli Kirjastus.

62. Shepard J., Carlson J. S. (2003). An Empirical Evaluation of School-Based Prevention Programs That Involve Parents. Psychology in the School, 40 (6), 641-656.

63. Sutton C. (2006). Helping Families with Troubled Children: A Preventive Approach. Hoboken, NJ: John Wiley.

64. Teich A. C. (1995). Võrdlev halduspoliitika. Sotsiaalse valiku poliitika Ameerikas, Euroopas ja Jaapanis. Tallinn

65. Tulva T. (1996). Sotsio-ökoloogiline teooria lastekaitsetöö lähtekohana. Teadusartiklite Kogumik. K. Suislepp (koost.)., Lastekaitse muutuvas ühiskonnas (5-18). Tallinn: TPÜ.

66. Tulva T., Viiralt I. (2001.) Võrgustikutöö võimalusi laste- ja pereprobleemide lahendamisel. Laps ja pere tänases Eestis, teadusartiklite kogumik, Tallinn.

67. Tuomi-Gröhn T., Engström Y. (2003). Conceptualizing Transfer: From Standard Notions to Developmental Perspectives. Between School and Work. T. TuomiGröhn, Y. Engeström (eds.). New perspectives on Transfer and Boundary-crossing. Pergamon, 19-38.

68. Veermäe K. (2004). Hariduskorralduse põhiprintsiipide rakendamisest Eestis. Juridica X, 712-721.

69. Viiralt I. (1999). Sensoorse integratsiooni häiretega koolieelne laps: toimetuleku toetamise võimalusi. Magistritöö referaat. TPÜ. Tallinn.

70. Viires P. (2008). Eesti kirjandus ja postmodernism. Tartu Ülikooli Kirjastus.

71. Vincent C. (1996). Parent Empowerment? Collective Action and Inaction in Education. The Annual Meeting of the American Educational Research Assosiation. USA: New York.

72. Vygotski L. (1981). Thought and language. Cambridge, MA: MIT Press.

73. Webster-Stratton C., Reid M. J. Stoolmiller M. (2008). Preventing conduct problems and improving school readiness: evaluation of the Incredible Years Teacher and Child Training Programs in high-risk schools. Journal of Child Psychology and Psychiatry 49:5, 471-488.

http: //web.ebscohost.com/ehost/pdfviewer/pdfviewer? vid=7\&hid=8\&sid=9242 2183-be60-4704-b716-f824243b0c8f\%40sessionmgr10. (28.07.2011)

74. Young M. F. D., Muller J. (2007) Truth and truthfulness in the sociology of educational knowledge. Theory and Research in Education 5 (2), 173-201. 
Theoretical and practical issues in the implementation of case-based networking ... 109

\section{Address for correspondence:}

Tiina Kallavus

Tartu Herbert Masing School

Vanemuise 33, Tartu 51014

E-mail: tiinakallavus@masing.tartu.ee 